\title{
CLINICAL AND IMMUNOLOGICAL PECULIARITIES OF PARASITIC INFECTIONS IN CHILDREN WITH DIGESTIVE SYSTEM DISORDERS IN WESTERN UKRAINE
}

\author{
K. T. HLUSHKO ${ }^{\bowtie}$, H. A. PAVLYSHYN, K. V. KOZAK \\ Department of Pediatrics No 2, I. Horbachevsky Ternopil National \\ Medical University, Ternopil, Ukraine; \\ 凶e-mail: glushko_kt@tdmu.edu.ua
}

Received: 29 January 2021; Accepted: 23 April 2021

\begin{abstract}
Diseases of the digestive system such as gastroduodenal disorders (GDD) and hepatobiliary diseases (HBD) are fairly common among children. At the same time, intestinal parasites are widespread gastrointestinal tract infectious agents. We examined 108 children with GDD $(n=54)$ and $\operatorname{HBD}(n=54)$ (mean age $11.8 \pm 4.3$ years) who were treated in a children's hospital. The following were performed: blood test for specific Ig to Ascaris lumbricoides, Toxocara canis; feces analysis for helminth eggs, Giardia cysts; and pinworm test. The serum level of interleukin-4 (IL-4) was measured in 97 of 108 children. Overall parasitic co-infections were found in $60.2 \%$ of children: giardiasis in $30.6 \%$, toxocariasis in $17.6 \%$, ascariasis seropositivity in $13.9 \%$ and enterobiasis in $8.3 \%$ of cases. Parasitic infections (PIs) occurred in $72.2 \%$ of the HBD group and in $48.2 \%$ of the GDD group $(P=0.01)$. Among the PIs only ascariasis was found more often in the HBD group (22.2\%) compared with the GDD group (5.6\%) $(P=0.01)$. The mean age of children who were positive for $\mathrm{PI}(\mathrm{PI}+)$ was $9.9 \pm 4.6$ years; while in the PI negative (PI-) group the mean age was $12.8 \pm 3.3$ years $(P<0.001)$. In GDD the IL-4 level in PI+ group was $9.3 \pm 0.9 \mathrm{pg} / \mathrm{ml}$ in the versus $6.9 \pm 1.8 \mathrm{pg} / \mathrm{ml}$ in the $P I-$ group $(P=0.02)$. Children with HBD and PI had higher IL-4 levels $(14.2 \pm 18.8 \mathrm{pg} / \mathrm{ml})$ compared to those without PI $(7.5 \pm 2.4 \mathrm{pg} / \mathrm{ml})(P=0.03)$. The differing impact on the course and immune response in children depending on co-infection with PIs indicates the need for additional testing for these infections.
\end{abstract}

K e y w o r d s: children, parasitic infections, digestive diseases, interleukin-4.

\section{Introduction}

Digestive diseases are some of the most common diseases in children. According to official statistics, the prevalence of digestive system disorders among children in Ukraine in 2017 was 111.74 per 1000 persons and was ranked second after respiratory system diseases. Upper gastrointestinal tract diseases such as gastritis, gastroduodenitis, gastric/ duodenal ulcers and functional biliary tract disorders are common in the pediatric population [1].

The most known and studied etiological agent of gastroduodenal diseases is the flagellated, spiralshaped, Gram-negative bacillus Helicobacter pylori (H. pylori), which is also a risk factor for developing peptic ulcers and gastric adenocarcinomas. It is estimated that the gastric mucosa in nearly half of the population worldwide is colonized with $H$. pylori. In spite of this, the occurrence of peptic ulcers is not this high among either the pediatric or adult population; only from 1 to $2 \%$ of adult individuals have gastric malignancies or mucosa-associated lymphoid tissue (MALT) lymphomas [2, 3].

Intestinal parasites are also well-known and widespread infectious agents. Both, helminths ["helminths" is the plural form of "helminth" but "helminthes" is a division of the animal kingdom and "helminthiasis" is the disease] and protozoa are very common among people living in developing countries [4]. According to the WHO (2020) soil-transmitted helminthic infections affect more than 1.5 billion people or $24 \%$ of the world's population and mainly in tropical and subtropical areas such as sub- 
Saharan Africa, America, China and East Asia [5]. In particular, one quarter of the entire population in sub-Saharan Africa was infected with one or more intestinal helminths, mainly the nematode or roundworms [6]. In Ukraine (2017), the prevalence of infectious and parasitic diseases was 54.2 per 1000 persons. However, there are no official data on the prevalence of specific helminthiasis in Ukraine [1]. It is believed that about $80 \%$ of all infected persons in Ukraine are children [7]. These data are consistent with the results of other researchers. In particular, almost half of school-aged children in sub-Saharan Africa are affected by one or more parasitic worms (2006) [6]. This predominance in children is due to various reasons, including behavioral factors that occur most often in children such as poor personal hygiene and pica disorder (eating soil/sand). In addition, children stay together for long periods of time (e.g., playing outside, while at kindergarten or school), which increases the chances of becoming infected and spreading infection. All these circumstances increase the likelihood of environmental contamination and transmission of helminths [6, 7].

The frequency and prevalence of parasitic infections depends on the region, climate zone, and population's socioeconomic status. It is believed that low socioeconomic status leads to the increased frequency of helminthic and protozoal infections. Therefore, parasitic infections are considered to be an infection of poverty [6]. It was estimated that intestinal helminths such as Ascaris lumbricoides (A. lumbricoides), Enterobius vermicularis (pinworm), Trichuris trichiura (human whipworm), Toxocara canis (T. canis) and protozoan Giardia intestinalis/lamblia are the parasites most often detected in Ukraine [7].

The etiological aspects, mechanism of transmission, pathogenesis and clinical manifestations of individual parasitic infections are well known [68]. However, the impact of intestinal helminths and parasites on the etiology and pathogenesis of various diseases including digestive diseases are still being studied and investigated.

The combination of $H$. pylori infection with parasitic infection is of particular interest. Protozoas modulate the immune response resulting in polarization of Th1 cells and with $H$. pylori co-infection can exacerbate inflammation and lead to digestive tract ulceration. On the other hand, intestinal helminths can polarize lymphocytes towards Th2, reduce inflammation and lead to a protective effect [4]. The anti-inflammatory Th2 immune response is more frequent in developing countries such as Africa, Asia and others where there is high helminthiasis prevalence. In contrast, pro-inflammatory Th17/Th1 responses are more typical for helicobacter gastritis in developed countries $[3,4,9,10]$.

However, according to our knowledge, such studies have not been conducted in a developing European country with a temperate climate.

The aim of our study was to evaluate the effect of co-infections of helminthiasis and giardiasis on the clinical course and anti-inflammatory immune response in children with gastroduodenal and functional biliary tract disorders.

\section{Materials and Methods}

This cross-sectional study was conducted in 108 children with gastroduodenal and hepatobiliary disorders. The mean age of participants was (11.1 \pm 4.3 ) years (range 2-17 years). Children were recruited from the Ternopil regional pediatric hospital. They were divided into two study groups based on the main pathology: the gastroduodenal disorders (GDD) group (54 children) and the hepatobiliary diseases (HBD) group (54 children).

The children's parents gave their written informed consent for the inclusion in the study. The procedures were explained to all children according to their age and their verbal consent was also received. The study was approved by the Bioethics Commission of the I. Horbachevsky Ternopil State Medical University (protocol No 24 from 27.08.2014) and was carried out in accordance with the Helsinki Declaration (2013).

The study inclusion criteria were patients with gastritis, duodenitis, gastroduodenitis, gastric or duodenal ulcers, or functional biliary disorders (i.e., functional disorders of gallbladder or biliary sphincter). The exclusion criteria were acute surgical pathology, gastrointestinal bleeding, any surgery within 2 weeks prior to study enrolment; liver, renal, heart failure; presence of such comorbidities such as atopic dermatitis, bronchial asthma and other allergic problems; pregnancy; alcohol abuse; any medication that may affect levels of interleukins; or critically ill patients.

Microscopic examination of feces for helminth eggs and Giardia cysts as well as the pinworm test were performed for all participants. Specific immunoglobulin G (Ig) antibody levels against $T$. canis were assessed in blood serum using the ELISA method in order to confirm toxocariasis because 
stool examination is not useful in humans since eggs are not excreted. Also specific IgG against $A$. lumbricoides was measured to assess seropositivity to this helminth. The serum level of interleukin-4 (IL-4) was tested in 97 children whose parents gave their consent for taking blood samples. IL-4 was assessed in order to study the anti-inflammatory immunological response. Esophagogastroduodenoscopy was performed in 54 children with GDD, however gastric biopsies were taken in only 22 children whose parents gave permission. $H$. pylori infection was confirmed using the ELISA method in all children with GDD and standard histological methods (formalin fixation, sampling, paraffin inclusion, sectioning, hematoxylin-eosin and Giemsa staining) in those children who underwent a biopsy. The diagnosis of "Toxocariasis" was made using exposure history, clinical signs, eosinophilia and the specific Toxocara antibody test [11].

Statistical data analysis was performed using the computer-based software package STATISTICA, version 10.0 (Stat Soft. Inc., Tulsa, USA). The determination of data normality was done using the Shapiro-Wilk test or Kolmogorov-Smirnov test. Differences in continuous variables were analyzed using the Student's $t$-test (data expressed as mean $\pm \mathrm{SD}$ ) or Mann-Whitney test (data expressed as median, range). The Kruskal-Wallis test for nonparametric data and one-way ANOVA for parametric data were used to compare three or more groups of sample data. The qualitative data were compared using the Pearson's Chi-square $\left(\chi^{2}\right)$ test. Spearman correlation was used to evaluate relationships involving ordinal variables. The level of statistical significance was accepted at $P<0.05$.

\section{Results}

A total of 54 children with GDD (group 1) and 54 children with HBD (group 2) were examined. Each group was also divided into two subgroups according to parasitic infection (PI) status. The general characteristics of the main study groups are presented in Table 1. In the GDD group, 26 children (48.15\%) were PI-positive (PI+) and 28 children (51.85\%) were PI-negative (PI-). In the HBD group, 39 children (72.22\%) were PI+ and 15 children (27.78\%) were PI-negative.

In additional, children with GDD were divided according to their $H$. pylori status: 18 children (33.3\%) were $H$. pylori-positive and 36 children (66.7\%) were $H$. pylori-negative. In order to investi- gate the interaction between PI and $H$. pylori infection, children with GDD were also divided into 4 subgroups: the $H$. pylori mono-infection subgroup included 9 (16.67\%) children, the mono-parasitic infection subgroup had 17 children (31.48\%), the coinfection with $H$. pylori and parasites subgroup had 9 children (16.67\%), and the subgroup without any infections had 19 children (35.18\%).

Overall, 65 children (60.2\%) were PI+ (26 in GDD group, 39 in HBD group; Table 1). While seropositivity for $A$. lumbricoides was found in $13.9 \%$ $(n=15)$ of children, eggs in feces were detected in only $0.9 \%(n=1)$. We included seropositive children in the PI+ subgroup because increased specific antibodies can indicate a specific immune response and can affect the results. Also, the parents of these children had denied any anthelmintic therapy for last 6 months. Seropositivity for A. lumbricoides was seen significantly rarely in the GDD group compared to the HBD group $(P=0.01)$. As for toxocariasis (from T. canis), in all seropositive children $(18.5 \%, n=20)$ there were also clinical signs and specific histories that confirmed the diagnosis. Enterobiasis (from E. vermicularis (pinworm)) was established in $8.3 \%$ of children $(n=9)$. Also, some children were coinfected with both Giardia and intestinal helminths.

The age of the patients was significantly different between the subgroups with and without PI $(9.9 \pm 4.5$ vs. $2.8 \pm 3.3$ years, $t=-3.6, P=0.0005)$. There was a moderate negative correlation between age and parasitic co-infections $(R=-0.32, P<0.05)$. However, the age difference was found only for giardiasis $(10.6 \pm 3.6$ years, $P=0.006)$ and for those who were seropositive for $A$. lumbricoides $(7.9 \pm 4.8$ years, $P<0.0001$ ).

In children with GDD, H. pylori infection was confirmed in $33.3 \%$ of children $(n=18)$. There were no differences between the frequencies of $H$. pylori infection and intestinal PIs in the GDD group. But infections by some specific intestinal helminths (Table 1$)$ such as T. canis $(16.7 \%)(P=0.046)$ and $E$. vermicularis (pinworm, 5.6\%) $(P<0.001)$, as well as seropositivity for $A$. lumbricoides $(5.6 \%)(P<0.001)$ were much less frequent than $\mathrm{H}$. pylori infections.

The clinical differences between GDD and HBD groups depending on the PI status are presented in Table 2. There were found that in GDD group in PI+ children abdominal pain related to physical activity (38.5\%) and liquid feces (15.4\%) occurred more often than in PI- subgroup (14.3\% and $0.0 \%)$ $(P<0.05)$, while in HBD group in PI+ children ir- 
Table 1. The main characteristics of the study groups

\begin{tabular}{|c|c|c|c|}
\hline Main characteristics & GDD group $(n=54) \mathrm{n}(\%)$ & HBD group $(n=54), n(\%)$ & $P$-value \\
\hline $\begin{array}{l}\text { Gender: } \\
\text { Boys } \\
\text { Girls }\end{array}$ & $\begin{array}{l}23(42.6 \%) \\
31(57.4 \%)\end{array}$ & $\begin{array}{l}32(59.3 \%) \\
22(40.7 \%)\end{array}$ & 0.08 \\
\hline $\begin{array}{l}\text { Place of residence: } \\
\text { Village } \\
\text { Town }\end{array}$ & $\begin{array}{l}28 \text { (51.9\%) } \\
26 \text { (48.2\%) }\end{array}$ & $\begin{array}{l}34 \text { (63.0\%) } \\
20(37.0 \%)\end{array}$ & 0.24 \\
\hline Age, years, $\mathrm{M} \pm \mathrm{SD}$ & $13.4 \pm 3.0$ & $8.7 \pm 4.1$ & $<0.001$ \\
\hline Parasitic infection negative (PI-) & $28(51.9 \%)$ & $15(27.8 \%)$ & 0.01 \\
\hline Parasitic infection positive (PI+) & $26(48.2 \%)$ & $39(72.2 \%)$ & 0.01 \\
\hline $\begin{array}{l}\text { Type of parasitic infection: } \\
\text { Giardia } \\
\text { T. canis } \\
\text { A. lumbricoides (seropositive) } \\
\text { E. vermicularis (pinworm) }\end{array}$ & $\begin{array}{c}15(27.8 \%) \\
9(16.7 \%) \\
3(5.6 \%) \\
3(5.6 \%)\end{array}$ & $\begin{array}{c}18(33.3 \%) \\
11(20.4 \%) \\
12(22.2 \%) \\
6(11.1 \%)\end{array}$ & $\begin{array}{l}0.53 \\
0.62 \\
0.01 \\
0.30\end{array}$ \\
\hline $\begin{array}{l}\text { Parasitic co-infections: } \\
\text { Giardia and T. canis } \\
\text { Giardia and E. vermicularis } \\
\text { Giardia and A. lumbricoides }\end{array}$ & $\begin{array}{l}3(5.6 \%) \\
2(3.7 \%) \\
1(1.9 \%) \\
0(0.0 \%)\end{array}$ & $\begin{array}{l}7(13.0 \%) \\
2(3.7 \%) \\
3(5.8 \%) \\
2(3.7 \%)\end{array}$ & 0.18 \\
\hline
\end{tabular}

Note. GDD - gastroduodenal disorders; HBD - hepatobiliary diseases; M - mean; SD - standard deviation

Ta ble 2. The main clinical peculiarities of the study groups

\begin{tabular}{|l|c|c|c|c|c|c|}
\hline \multirow{2}{*}{\multicolumn{1}{|c|}{ Clinical signs }} & \multicolumn{2}{|c|}{ GDD group $(n=54)$} & \multirow{2}{*}{$P^{*}$} & \multicolumn{2}{c|}{ HBD group $(n=54)$} & \multirow{2}{*}{$P^{* *}$} \\
\cline { 2 - 3 } & PI+ $(n=26)$ & PI- $(n=28)$ & & PI+ $(n=39)$ & PI- $(n=15)$ & \\
\hline Abdominal pain & $26(100.0 \%)$ & $23(82.1 \%)$ & 0.02 & $18(46.2 \%)$ & $8(53.3 \%)$ & 0.63 \\
\hline $\begin{array}{l}\text { Abdominal pain related } \\
\text { to physical activity }\end{array}$ & $10(38.5 \%)$ & $4(14.3 \%)$ & 0.04 & $6(15.4 \%)$ & $4(26.7 \%)$ & 0.34 \\
\hline Liquid feces & $4(15.4 \%)$ & $0(0.0 \%)$ & 0.03 & $6(15.4 \%)$ & $1(6.7 \%)$ & 0.39 \\
\hline Irritability & $3(11.5 \%)$ & $3(10.7 \%)$ & 0.96 & $12(30.8 \%)$ & $0(0.0 \%)$ & 0.01 \\
\hline Intoxication clinical signs & $15(57.7 \%)$ & $16(57.1 \%)$ & 0.96 & $27(69.2 \%)$ & $6(40.0 \%)$ & 0.04 \\
\hline
\end{tabular}

Note. GDD - gastroduodenal disorders; HBD - hepatobiliary diseases. PI+ - parasitic infection positive (confirmed); PI- - parasitic infection negative. $P^{*}-P$-value between PI+ and PI- GDD subjects; $P^{* *}-P$-value between PI+ and PIHBD subjects

ritability (30.8\%) and intoxication clinical signs (69.2\%) were more often than in PI- subgroup (0.0\% and $40.0 \%)(P<0.05)$.

The serum levels of IL-4 depending on which parasite species was found are presented in Table 3 (comparisons with PI- children were done). It was found that the level of IL-4 was higher in children infected with intestinal helminths and did not differ in subjects with Giardia infection.

Serum IL-4 levels were significantly higher in the HBD group $(12.3 \pm 15.7 \mathrm{pg} / \mathrm{ml}$; $(8.7 ; 7.9-9.5 \mathrm{pg} /$ $\mathrm{ml})$ ) than in the GDD group $(8.0 \pm 3.6 \mathrm{pg} / \mathrm{ml}$; $(7.5$; $5.9-8.9 \mathrm{pg} / \mathrm{ml}))(P=0.004)$.

There were statistically different serum IL-4 levels in the two study groups (GDD, HBD) depending on the type of PI (Table 4). It was found that in children infected with intestinal helminths the levels of IL-4 were higher in both study groups, while in Gardia positive children it did not differ from PIalso in both study groups. The level of IL-4 in children with separate species of intestinal parasites was not assessed due to the small number of cases. 
Ta ble 3. Serum interleukin-4 (IL-4) levels in the children in relation to parasite species

\begin{tabular}{|l|c|c|c|}
\hline \multicolumn{1}{|c|}{ Groups of patients } & Number of children, $n=97$ & $\begin{array}{c}\text { Serum IL-4, pg/ml, } \\
\text { M } \pm \text { SD, Me; 25\%-75\% }\end{array}$ & $P$ \\
\hline Parasitic infection negative (PI-) & 42 & $7.2 \pm 2.0$ & - \\
\hline Parasitic infection positive (PI+) & 5 & $12.0 \pm 14.6$ & $<0.001$ \\
\hline Giardia & & $8.8 ; 7.5-10.5$ & \\
\hline T. canis & 31 & $10.2 \pm 11.8$ & 0.08 \\
\hline A. lumbricoides (seropositive) & 14 & $8.5 ; 6.1-9.3$ & \\
\hline E. vermicularis (pinworm) & 14 & $9.65 ; 8.4-15.7$ & \\
& & $9.5 \pm 2.1$ & 0.001 \\
\hline
\end{tabular}

Note. $P$ in comparison with "parasitic infection” group; M - mean; SD - standard deviation; Me - median

Ta b le 4. Serum interleukin-4 (IL-4) levels in the children in relation to parasitic infection (PI) status

\begin{tabular}{|l|c|c|c|c|c|c|}
\hline \multirow{2}{*}{ Patient group } & \multicolumn{5}{|c|}{ Serum IL-4, pg/ml, M \pm SD, Me; 25\%-75\% } \\
\cline { 2 - 7 } & GDD group $(n=51)$ & $P^{*}$ & HBD group $(n=46)$ & $P^{* *}$ \\
\hline Parasitic infection negative (PI-) & $n=27$ & $6.9 \pm 1.8$ & - & $n=15$ & $7.5 \pm 2.4$ & - \\
& & $6.5 ; 5.9-8.2$ & & & $8.2 ; 7.2-8.9$ & \\
\hline Parasitic infection positive (PI+) & $n=24$ & $9.3 \pm 4.6$ & 0.02 & $n=31$ & $14.2 \pm 18.8$ & 0.03 \\
& & $8.45 ; 5.9-11.4$ & & & $8.9 ; 8.0-10.2$ & \\
\hline Gardia positive (+) & $n=15$ & $7.6 \pm 3.4$ & 0.40 & $n=16$ & $12.8 \pm 15.9$ & 0.11 \\
& & $6.1 ; 5.3-8.9$ & & & $8.75 ; 7.85-9.75$ & \\
\hline Intestinal helminths & $n=12$ & $11.4 \pm 4.9$ & $<0.001$ & $n=20$ & $14.0 \pm 19.1$ & 0.02 \\
& & $9.45 ; 8.35-14.35$ & & & $9.0 ; 8.25-10.3$ & \\
\hline
\end{tabular}

Note. $P^{*}$ in comparison with GDD "parasitic infection” group; $P^{* *}$ in comparison with HBD "parasitic infection” group; M - mean; SD - standard deviation; Me - median; GDD - gastroduodenal disorders; HBD - hepatobiliary diseases

PI status and H. pylori co-infection significantly influenced the level of IL-4 in the GDD group (Fig.). The highest level of IL-4 was found in children with parasitic mono-infection (Hp- $\mathrm{PI}+)(10.0 \pm 4.7 \mathrm{pg} / \mathrm{ml}$; $(8.7 ; 6.8-10.6 \mathrm{pg} / \mathrm{ml}))$ and this difference was significant in comparison with the $H$. pylori mono-infection subgroup (Hp+ PI-) $(6.7 \pm 2.3 \mathrm{pg} / \mathrm{ml} ;(6.5 ; 4.7-$ 8.0 fections (Hp- PI-) $(7.0 \pm 1.5 \mathrm{pg} / \mathrm{ml} ;(6.65 ; 6.0-8.2$ $\mathrm{pg} / \mathrm{ml}))(P=0.02)$.

The IL-4 level in the GDD group differed depending on the type of childhood PI. IL-4 levels were not significantly different between the $H$. pylori and Giardia co-infection subgroup ( $\left.\mathrm{Hp}^{+} \mathrm{G}+\right)$ (7.3 $\pm 4.7 \mathrm{pg} / \mathrm{ml}), \mathrm{H}$. pylori mono-infection subgroup $(\mathrm{Hp}+\mathrm{PI}-)(6.7 \pm 2.3 \mathrm{pg} / \mathrm{ml})$ and Giardia mono-infection subgroup $(\mathrm{Hp}-\mathrm{G}+)(7.8 \pm 2.1 \mathrm{pg} / \mathrm{ml})(P=0.46)$.
However, the IL-4 level depended on the helminth co-infection. The IL-4 level was higher in the helminth mono-infection group $(11.3 \pm 5.4 \mathrm{pg} / \mathrm{ml})$ compared to the $H$. pylori mono-infection group $(P=0.005)$. Significant differences in serum IL-4 levels between the $H$. pylori mono-infection group (Hp+ PI-) $(6.7 \pm 2.3 \mathrm{pg} / \mathrm{ml})$ and the H. pylori and helminth co-infection group $(12.1 \pm 1.3 \mathrm{pg} / \mathrm{ml})$ were also found $(P=0.03)$.

\section{Discussion}

H. pylori, intestinal helminths and Giardia intestinalis remain widespread and common infectious agents in children in the general population and among children with digestive system disorders $[2,3,6,7,10,12]$. According to our results, H. py- 


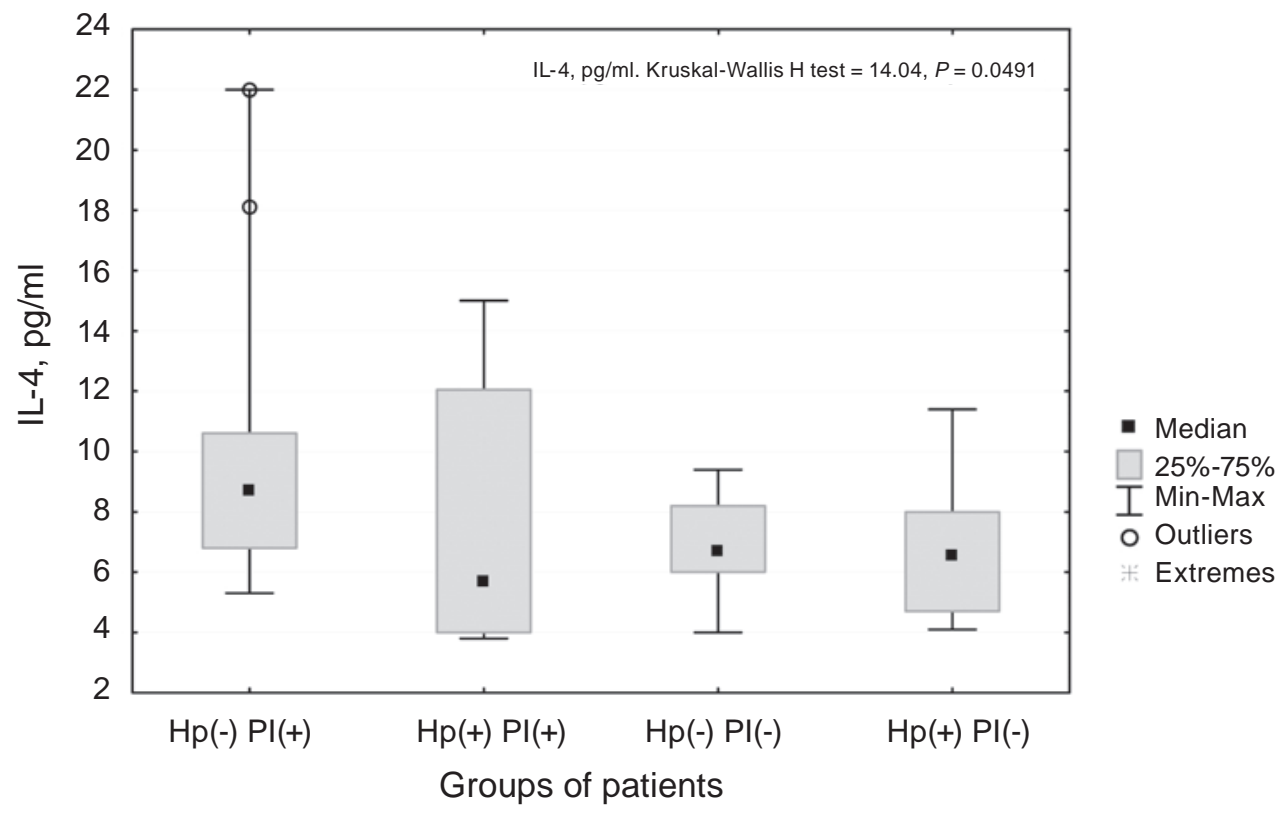

Serum interleukin-4 (IL-4) levels in the gastroduodenal disorders (GDD) group in relation to infections with helminths, Giardia or H. pylori or co-infections. Hp - H. pylori infection; PI - parasitic infection

lori infection was confirmed in $33.3 \%$ of the GDD group while other researchers have estimated it is from $50 \%$ to $70 \%$ depending on the region studied $[2,3,10,13]$. However, some studies found the same rates of $H$. pylori infections in children with abdominal pain and dyspeptic syndrome [14, 15], as in our study. These findings confirm that the frequency of $\mathrm{H}$. pylori infection varies depending on the region.

In recent years, the frequency of studies about co-infection by $H$. pylori and various PIs has increased [2-4, 6, 9, 12, 13]. In our research study, intestinal helminths/protozoa were found in $60.2 \%$ of patients with digestive system disorders. They were more prevalent in the HBD group (72.2\%) than in the GDD group (48.2\%). Our study has confirmed data that PI generally occur more often in younger children than in older ones or adults [6, 7]. The mean age of PI+ children was $9.9 \pm 4.5$ years, while that of PI- children was $12.8 \pm 3.3$ years. However, age of infected children also depended on the species and was confirmed for giardiasis and ascariasis. These findings can be explained by peculiarities of their life cycle and route of transmission.

According to our results, the most frequent parasite was Giardia, which was found in $30.5 \%$ of children but with no difference between the GDD (27.8\%) and HBD (33.3\%) groups. The connection between giardiasis and abdominal pain and diarrhea in children and adults was confirmed in many other studies. For example, a study conducted in northeast Ethiopia showed that PI occurred in 38.3\% of upper gastrointestinal symptomatic adult patients and $\mathrm{Gi}$ ardia was found in 22.3\% [12]. Another study conducted in Yemen revealed that Giardia was detected only in $10 \%$ of children with abdominal complaints (recurrent and chronic abdominal pain, gastritis, dyspepsia, nausea, vomiting, chronic diarrhea) with prevalence among younger children $(<5$ years) [16]. In our study Giardia-positive children were older (10.6 \pm 3.4 years) which also concurred with another study [14]. Also according to Turkish data, 30.6\% of children with recurrent abdominal pain were Giardia-positive [13]. We suggest that the frequency of giardiasis can vary depending on climate, socioeconomic level of the population, quality of water, educational level and other factors.

We found that seropositivity for A. lumbricoides occurred more often in the HBD group (22.2\%) compared to the GDD group (5.6\%). Infection with A. lumbricoides had significant age differences, with mean ages of $7.9 \pm 4.8$ years in A. lumbricoidesseropositive children and $11.6 \pm 4.8$ years in $A$. lumbricoides-seronegative children $(P=0.0002)$. These results concur with well-known data that ascariasis predominates in younger children with the highest prevalence in ages less than 5 years. Abdominal pain and hepatobiliary disorders are known consequences of A. lumbricoides infection [7, 8]. 
Other intestinal helminths such as T. canis and E. vermicularis (pinworm) occurred equally as often in the GDD and HBD groups. There was no age difference between infected and non-infected children, but the frequency of infection, in particular that for E. vermicularis was low.

There were no differences in frequency between $H$. pylori and Giardia infections, but $T$. canis (16.7\%), A. lumbricoides (5.6\%) and pinworm (5.6\%) were detected significantly less in the GDD group. Parasitic mono-infection was diagnosed in $31.5 \%$, H. pylori mono-infection was found in $16.7 \%$ and co-infection between $H$. pylori and PI was in $16.7 \%$ of children. These findings can be explained by the fact that both $H$. pylori and parasites share the same estimated risk factors (poor hygiene and sanitation, low socioeconomic conditions) [15]. Several studies have reported the relationship of co-infection between Giardia and $H$. pylori in symptomatic and asymptomatic patients, but the frequency of such co-infection was different $[4,12,14-18]$. The study conducted in Turkey showed that the frequency of co-infection between H. pylori and Giardia in symptomatic children was $22.4 \%$ compared to $6.8 \%$ in the control group [13]. At the same time, our results have shown that their co-infection occurs only in $13.0 \%$. Another study carried out in northeast Ethiopia showed that incidence of PI in $\mathrm{H}$. pylori-positive adults was also higher (44.3\%) and was significantly associated with Giardia [12].

According to our results, co-infection between $H$. pylori and intestinal helminths ( $T$. canis and A. lumbricoides) was found in only 5.6\%. Coinfection data vary in different studies. The study in Colombia has shown that the frequency of $\mathrm{H}$. pylori co-infection with A. lumbricoides in children aged 1-6 years varied 9-89\% depending on the region and climate [18]. The study conducted in central Ethiopia found that $23 \%$ of school-age children were coinfected with $H$. pylori and any intestinal parasite while $18.7 \%$ were co-infected with $H$. pylori and any protozoa, but the incidence of enterobiasis $(1.4 \%)$ or ascariasis $(0.2 \%)$ was also low [9]. We suggest that it is necessary and important to continue assessing the frequency of co-infection by $H$. pylori and intestinal helminths in symptomatic and asymptomatic children of different ages in Ukraine.

We found that the serum IL-4 level was significantly higher in the HBD group $(12.0 \pm 15.8 \mathrm{pg} /$ $\mathrm{ml})$ compared to the GDD group $(8.0 \pm 3.6 \mathrm{pg} / \mathrm{ml})$, which may be related to a higher parasite burden in the HBD group as a consequence of the younger age of the children and correspondingly poorer personal hygiene. Also, in the GDD group the immune response was shifted to Th1-dependent due to the influence of $H$. pylori-infection $[1,3,4,10]$. Further investigation confirmed this assumption. We found that IL-4 levels in PI+ children of both the GDD group $(9.3 \pm 4.6 \mathrm{pg} / \mathrm{ml})$ and HBD group $(14.2 \pm 18.8 \mathrm{pg} /$ $\mathrm{ml})$ were significantly higher than in PI- children. In addition, intestinal helminths had the greatest impact on serum IL-4 levels in both HBD and GDD groups. Serum IL-4 levels in children co-infected with intestinal helminths were higher than in PI- children, while levels in the Giardia infection group did not differ. The study of Guo et al. also confirmed that the IL-4 level was higher in children infected with intestinal helminths (ascaris, hookworm, whipworm, pinworm infections), regardless of clinical symptoms or species of the parasites [20]. Promotion of the Th2predominant response by helminths leads to immune suppression and intensification of regeneration in the gastrointestinal tract [4]. The IL-4 level did not differ between the Giardia-positive and PI- groups because this parasitic infection refers to single-celled protozoan organisms which promote polarization of lymphocytes towards the Th1 response and is characterized by secretion of the pro-inflammatory cytokines IL-2, IL-12 and IFN- $\gamma$ which in turn leads to increased tissue damage [4].

Our study confirmed that co-infection with H. pylori and Giardia did not affect the serum IL-4 level, whereas this level was significantly higher in the helminth mono-infection group in comparison to the $H$. pylori mono-infection group. Co-infection with $H$. pylori and helminths significantly increased the level of IL-4 in comparison with the $H$. pylori mono-infection group. These findings can also be explained by the fact that intestinal parasitic infections can affect inflammatory and anti-inflammatory responses to $H$. pylori. And this response can vary depending on the species of protozoa or helminths and can probably vary with the stage of their life cycle (intestinal phase or migration phase). It is wellknown that $\mathrm{H}$. pylori infection as well as Giardia promotes the Th1 immune response, whereas helminths increase the Th2 immune response and thus, the IL-4 level was increased in the group with coinfection by $H$. pylori and helminths $[3,4,9,10]$. The influence of such co-infection on the direction of the immune response was also confirmed in several studies. In particular, the study conducted in Columbia among $H$. pylori-positive children and 
adults confirmed that co-infection with an intestinal helminth (A. lumbricoides) increased the IgE level and anti-inflammatory Th2-IgG1 response. Whereas co-infection with the single-cell parasite Toxoplasma gondii increased the Th1-associated IgG2 level but this occurred only in those seronegative for A. lumbricoides [18]. These data also confirmed that even in those seropositive for A. lumbricoides, the Th2 immune response dominates, which was also found in our study, although the number of cases was small. A study conducted by Fuenmayor-Boscán et al. revealed that the level of IL-4 in gastric mucosa of adults co-infected with intestinal helminths and $H$. pylori was increased while the expression of proinflammatory cytokines was reduced [17].

Therefore, it can be considered that co-infection with Giardia and helminths has an impact on the clinical course and immune response in children with gastroduodenal and functional biliary tract disorders. The current study has a limitation in the small number of children in every studied subgroup. In order to obtain additional data, further studies of immunological responses to co-invasions during parasitic infections are needed.

Conclusion. It was shown that giardiasis was predominant (30.6\%) in children of both diseases groups (hepatobiliary and gastroduodenal). However, as for helminthiasis, their frequency differed in children depended on the age and the main gastroduodenal or hepatobiliary pathologies.

In children with upper gastrointestinal pathology, parasitic mono-infection (31.5\%) occurred more often than $H$. pylori mono-infection (16.67\%) or coinfection with $H$. pylori and parasites (16.67\%).

Co-infection with intestinal parasites had an impact on the clinical course of gastroduodenal and hepatobiliary pathologies and also on the immunological response, which depended on the parasitic species and the presence of $H$. pylori co-infection.

The study findings encourage us to recommend screening for widespread parasitic infections such as giardiasis, toxocariasis and ascariasis in symptomatic children with upper gastrointestinal pathology and hepatobiliary diseases.

Conflict of interest. Conflict of interest. Authors have completed the Unified Conflicts of Interest form at http://ukrbiochemjournal.org/wp-content/ uploads/2018/12/coi_disclosure.pdf and declare no conflict of interest.
Funding. The study was not funded by any sources.

Acknowledgments. We thank Cedars-Sinai Medical Center's International Research and Innovation in Medicine Program and the Association for Regional Cooperation in the Fields of Health, Science and Technology (RECOOP HST Association) for their support of our study and our organization as a participating Cedars-Sinai Medical Center - RECOOP Research Center (CRRC).

\section{КЛІНІЧНІ ТА ІМУНОЛОГІЧНІ ОСОБЛИВОСТІ ПАРАЗИТАРНИХ ІНФЕКЦІЙ В ДІТЕЙ ІЗ РОЗЛАДАМИ ТРАВНОЇ СИСТЕМИ В ЗАХІДНІЙ УКРАЇНI}

\section{К. Т. Глушко ${ }^{\bowtie}$, Г. А. Павлишин, К. В. Козак}

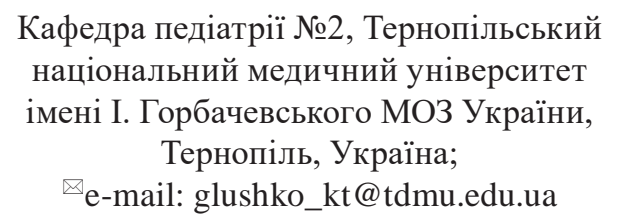

Такі захворювання травневої системи, як гастродуоденальні (ГДЗ) та гепатобіліарні розлади (ГБР) досить поширені серед дітей. У той же час широко розповсюдженими інфекціями шлунково-кишкового тракту є кишкові паразити. Нами було обстежено 108 дітей із ГДЗ $(n=54)$ та ГБР $(n=54)$, середній вік $11,8 \pm 4,3$ років, які проходили лікування в дитячій лікарні. Були проведені: аналіз крові на специфічні Ig до Ascaris lumbricoides, Toxocara canis; аналізи на яйця гельмінтів та цисти лямблій; тест на ентеробіоз. Визначено рівень інтерлейкіну-4 (IL-4) в сироватці крові у 97 із 108 дітей. Загалом коінфікування паразитами виявлено у 60,2\%: лямбліоз - у 30,6\%, токсокароз - у 17,6\%, аскаридоз (серопозитивні) - у 13,9\%, ентеробіоз - у $8,3 \%$ випадків. Паразитарні інвазії (ПІ) траплялись у $72,2 \%$ в ГБР групі та у $48,2 \%$ із ГДЗ $(P=0,01)$. Із них лише аскаридоз переважав у ГБР групі $(22,2 \%)$, ніж у ГД3 $(5,6 \%)(P=0,01)$. Середній вік дітей з підтвердженими ПІ (ПІ+), становив 9,9 $\pm 4,6$ років, тоді як у ПІ - негативних (ПІ-) $-12,8 \pm 3,3$ років $(P<0.001)$. Рівень IL-4 при ГДЗ в групі (ПI+) становив 9,3 $\pm 0,9$ пг/ мл, тоді як в (ПІ-) $-6,9 \pm 1,8$ пг/мл $(P=0,02)$. IL-4 за ГБР в (ПІ+) становив 14,2 $\pm 8,8$ пг/мл, а в (ПІ-) 
$7,5 \pm 2,4$ пг/мл $(P=0,03)$. Різний вплив на перебіг та імунну відповідь залежно від коінфекції лямбліями або кишковими паразитами свідчить про необхідність додаткового скринінгу на ці інфекції в дітей.

К л ю ч о в і с ло в а: діти, паразитарні інфекції, захворювання органів травлення, інтерлейкін-4.

\section{Reference}

1. Annual report on the health's state of the population, the sanitary-epidemic situation and the results of the health care system in Ukraine in 2017. Kyiv: MVC «Medinform», 2018. 458 p. (In Ukrainian).

2. Figueiredo CA, Marques CR, Costa Rdos S, da Silva HBF, Alcantara-Neves NM. Cytokines, cytokine gene polymorphisms and Helicobacter pylori infection: friend or foe? World $J$ Gastroenterol. 2014; 20(18): 5235-5243.

3. de Brito BB, da Silva FAF, Soares AS, Pereira VA, Santos MLC, Sampaio MM, Neves PHM, de Melo FF. Pathogenesis and clinical management of Helicobacter pylori gastric infection. World $J$ Gastroenterol. 2019; 25(37): 5578-5589.

4. Krzyżek P, Gościniak G. Frequency and immunological consequences of Helicobacter pylori and intestinal parasite co-infections: a brief review. Ann Parasitol. 2017; 63(4): 255-263.

5. World Health Organization. Soil-transmitted helminthic infection. Geneva: WHO, 2018. Available at: https://www.who.int/news-room/ fact-sheets/detail/soil-transmitted-helminthinfections (accessed 14 January 2020).

6. Harhay MO, Horton J, Olliaro PL. Epidemiology and control of human gastrointestinal parasites in children. Expert Rev Anti Infect Ther. 2010; 8(2): 219-234.

7. Yershova IB, Mochalova HO, Lokhmatova IA, Manashova MH, Petrenko OV. Non-specific manifestations of helminthiasis in children. Child's Health. 2015; (8.68): 45-50. (In Russian).

8. Leung AKC, Leung AAM, Wong AHC, Hon KL. Human Ascariasis: An Updated Review. Recent Pat Inflamm Allergy Drug Discov. 2020; 14(2): 133-145.

9. Spotts H, Walelign S, Tesfaye M, Desta K, Tsegaye A, Taye B. Concurrent infection of intestinal parasites and Helicobacter pylori among school-age children in Central Ethiopia. Parasite Epidemiol Control. 2020; 11: e00177.

10. D'Elios MM, Amedei A, Benagiano M, Azzurri A, Del Prete G. Helicobacter pylori, $\mathrm{T}$ cells and cytokines: the "dangerous liaisons". FEMS Immunol Med Microbiol. 2005; 44(2): 113-119.

11. Woodhall DM, Fiore AE. A Toxocariasis: A Review for Pediatricians. J Pediatric Infect Dis Soc. 2014; 3(2): 154-159.

12. Seid A, Tamir Z, Kasanew B, Senbetay M. Coinfection of intestinal parasites and Helicobacter pylori among upper gastrointestinal symptomatic adult patients attending Mekanesalem Hospital, northeast Ethiopia. BMC Res Notes. 2018; 11(1): 144.

13. Zeyrek D, Zeyrek F, Cakmak A, Cekin A. Association of Helicobacter pylori and giardiasis in children with recurrent abdominal pain. Turkiye Parazitol Derg. 2008; 32(1): 4-7.

14. Nemchenko UM, Grigorova EV, Ivanova EI, Kungurtseva EA, Tunik TV, Savelkaeva MV, Petrova IV, Rychkova LV. Frequency of Helicobacter pylori infection and giardiasis in children of different age groups with abdominal pain and dyspeptic syndrome according to the fecal immunochromatographic method. $J$ Infectol. 2018; 10(1): 24-28.

15. Ibrahim A, Ali YBM, Abdel-Aziz A, ElBadry AA. Helicobacter pylori and enteric parasites co-infection among diarrheic and non-diarrheic Egyptian children: seasonality, estimated risks, and predictive factors. $J$ Parasit Dis. 2019; 43(2): 198-208.

16. Bin Mohanna MA, Al-Zubairi LM, Sallam AK. Prevalence of Helicobacter pylori and parasites in symptomatic children examined for Helicobacter pylori antibodies, antigens, and parasites in Yemen. Saudi Med J. 2014; 35(11): 1408-1411.

17. Fuenmayor-Boscán A, Hernández-Rincón I, Arismendi-Morillo G, Mengual E, Rivero Z, Romero G, Lizarzábal M, Álvarez-Mon M. Changes in the severity of gastric mucosal inflammation associated with Helicobacter pylori in humans coinfected with intestinal helminths. Indian J Gastroenterol. 2020; 39(2): 186-195.

18. Hussain Z, El-Omar E, Lee YY. Dual infective burden of Helicobacter pylori and intestinal 
parasites: Good or bad news for the host? Indian J Gastroenterol. 2020; 39(2): 111-116.

19. Ek C, Whary MT, Ihrig M, Bravo LE, Correa P, Fox JG. Serologic evidence that ascaris and toxoplasma infections impact inflammatory responses to Helicobacter pylori in Colombians. Helicobacter. 2012; 17(2): 107-115.
20. Guo AY, Lin XM, Zhang YQ, Wu H. The levels of IL-4, IL-9, and IgE in patients infected with intestinal helminths and their clinical values. Chinese J Parasitol Parasitic Dis. 2015; 33(2): 110-113. (In Chinese). 